\title{
Ennakointi osana investoineiden maitotilojen strategista suunnittelua
}

\author{
Susanna Lahnamäki-Kivelä \\ JAMK Biotalousinstituutti, Tuumalantie 17,43130 Tarvaala, susanna.lahnamaki-kivela@jamk.fi
}

Tutkimuksessa on kokonaisuutena kolme tasoa, jotka ovat maitotilayrittäjien ennakointimenetelmät, tulevaisuustiedon hyödyntäminen maitotilayrittäjien strategisissa valinnoissa sekä maitotiloilla toteuttavat johtamismallit. Tutkimuksen tarkoituksena on tunnistaa maitotilayrittäjien käyttämiä ennakointimenetelmiä, joita he ovat hyödyntäneet suunnitellessaan oman yrityksensä kehittämispolkua. Maidontuotannon laajennuksiin investoineet tilat ovat valikoituneet tutkimuksen kohderyhmäksi, sillä niiden yrittäjät ovat pääsääntöisesti edelleen kehittämässä omaa yritystään pitkällä aikajänteellä. Maitotilojen investoinnit ovat yrittäjille strategisia valintoja, jotka ohjaavat muun muassa yrityksen toimintaa, muita investointiratkaisuja, työnkäyttöä sekä mahdollisia lisäinvestointeja yli 10 vuoden aikajänteellä. Nopean rakennemuutoksen aikana ja markkinoiden epävarmuuden lisääntyessä strategisen ennakoinnin merkitys kasvaa maataloudessa ja yksittäisissä maatilayrityksissä. Ennakointia voidaan suorittaa useilla eri tasoilla ja hyödyntäen monipuolisia kanavia päätöksentekoa tukevan tiedon keräämiseksi. Tutkimuksen erityisenä kiinnostuksen kohteena ovat kysymykset, jotka liittyvät maitotilayrittäjien strategiseen ennakointiin, yrityksen strategisessa suunnittelussa käytettyyn tulevaisuustietoon ja tulevaisuustiedon keräämiseen käytetyt kanavat. Heikot signaalit, niiden tunnistaminen ja tunnistamiseen käytetyt tietokanavat sekä heikkojen signaalien vaikutus tulevaisuustiedon muodostamiseen ovat yksi tarkempi tutkimuksen kiinnostuksen kohde. Tutkimus kohdentuu alueille, joilla nurmirehuntuotannolla ja sen seurauksena kotieläintaloudella on maataloussektorin sisällä vahva painoarvo ja joilla aktiivisesti investoidaan maidontuotantoon. Tutkimuksen aineisto muodostuu sekä haastatteluaineistoista että massaaineistoista. Tutkimusaineiston analysoinnissa käytetään sekä kvalitatiivisia että kvantitatiivisia aineiston analysointimenetelmiä.

Asiasanat: ennakointi, tulevaisuustieto, maitotilat, strateginen suunnittelu 


\section{Johdanto}

Kirjallisuuskatsauksen taustalla on halu selvittää, kuinka paljon on aiemmin tehty tutkimusta, jossa keskitytään maitotilayrittäjien toteuttamaan tulevaisuuden ennakointiin osana oman tilan strategiatyötä. Strateginen johtaminen ja sen merkitys kasvavat yrityskoon kasvaessa. Suomen maataloudessa on edelleen vahva rakennekehitys, joka johtaa tilamäärän vähenemiseen ja samaan aikaan jäljelle jäävien tilojen kokoluokan kasvuun (LUKE 2016). Kokoluokan kasvua perustellaan muun muassa paremmalla kannattavuudella, joka on skaalaetujen kautta saavutettavissa (Valtioneuvoston kanslia 2017). Markkinatilanteen muutokset ovat maidontuotannossa vauhdittaneet rakennekehitystä aiheuttaen tilamäärän laskun ja samaan aikaan tilakoon suurenemiseen (Kuva 1.).

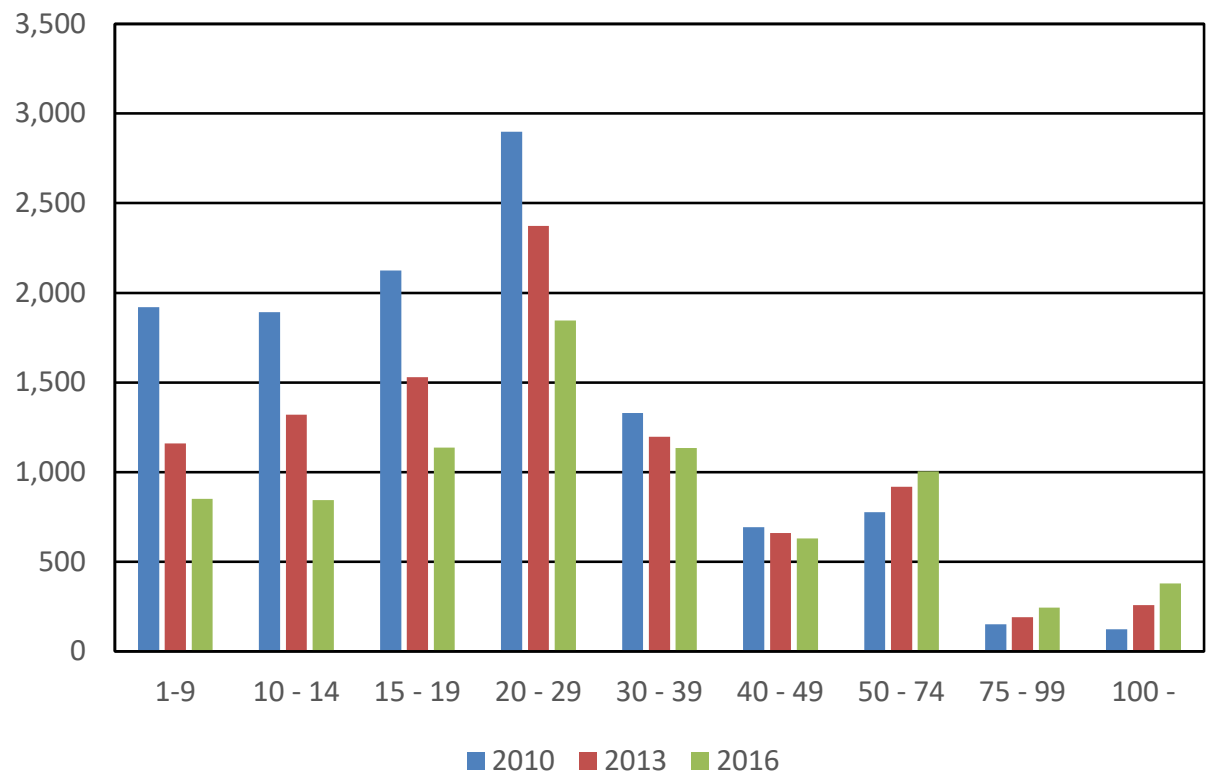

Kuva 1. Lypsykarjatilojen määrät kokoluokittain vuosina 2010, 2013 ja 2016. Lähde: Luonnonvarakeskus, Maataloustilastot

Yrityskoon kasvaessa lisääntyvät johtamisosaamisen tarve ja yrityksen strategisen suunnittelun merkitys. Yrittäjien riittävä koulutus on tärkeää tilojen kasvulle ja kehittymiselle. Osa yrityksen strategista suunnittelua on yrityksen tulevan kehityskaaren suunnittelu ja tavoitteiden asetanta pitkällä aikavälillä. Tilalla tehtävä strategiatyö ei kuitenkaan saa olla kertaluontoinen laadinta, vaan jatkuvasti päivittyvä ja toimintaympäristön muutoksiin reagoiva yrityksen johtamisen työkalu (Olson 2004).

Maataloudessa yleisesti pääomaa sitoutuu yritykseen toimintaan pitkäksi aikaa ja pääoman kierto on hidasta. Tämä asettaa haasteita yrityksen toiminnan kehittämiselle ja mahdollisille suunnanmuutoksille, kun sitoutunut pääoma ei ole helposti realisoitavissa rahaksi. Se hidastaa uuden liiketoiminnan kehittämistä ja rahoittamista. Maidontuotannon kehittymistä tarkasteltaessa on havaittu korvaus- ja uudisinvestointien vähäinen määrä suhteessa lopettaviin tiloihin. Investointihalukkuuteen vaikuttavat vallitseva markkinatilanne ja investointipolitiikka (VNK 2017). Myös maidon tuottajahinnalla ja sen kehitysnäkymillä on vaikutusta yrittäjien halukkuuteen sitoa pääomia maidontuotantoon ja lähteä rakentamaan uutta tuotantokapasiteettia.

Maataloustuotantoon liittyy useita erilaisia lainsäädännössäkin määritettyjä vaatimuksia paitsi itse alkutuotantoon, myös elintarvikkeiden tuoteturvallisuuteen ja tuotantoympäristöstä huolehtimiseen. Ainoastaan lakisääteiset asiat eivät vaikuta alkutuotantoon vaan myös yritysvastuullisuuden näkökulmat ja kuluttajaryhmien kiinnostus ruoan alkuperään sekä tuotantoon. Nämä kaikki yhdessä vaikuttavat maitotilayrittäjän toimintaympäristöön ja päätöksentekoon yrityksen kehittämisessä (Olson 2004). 
Voimakkaita ja jo tunnistettuja kehittämissuuntia nimitetään trendeiksi. Ne vaikuttavat yhteiskunnassa eri tavoin ja ovat pitkään jatkuvia. Selvästi tunnistettavien paineita ja vaatimuksia tuotannolle aiheuttavien asioiden lisäksi on tunnistettu globaaleja megatrendejä, jotka vaikuttavat kaikkeen toimintaan. Megatrendille on ominaista sen jatkuvuus yli sukupolvien ja voivat vaikuttaa ihmiseen yleisesti maapallolla (Saritas ja Smith 2011). Megatrendejä on kuvattu useissa eri lähteissä, suomalaisen sovellutuksen tekee vuosittain Suomen Itsenäisyyden Juhlarahasto SITRA.

Edellä kuvatusta on havaittavissa monimuotoisia maatalousyrittäjien toimintaan vaikuttavia asioita, osaan yrittäjät ovat valmistautua ennakolta, osaan on pystyttävä reagoimaan tarpeen tullessa. Tämä vaatii yrittäjältä kykyä seurata toimintaympäristön muutoksia ja mahdollisia kehityssuuntia sekä pohtia viedä tehtyjen havaintojen pohjalta tehdyt päätökset osaksi maatilayrityksen johtamista. Tässä paperissa kuvataan lyhyesti tehdyn kirjallisuuskatsauksen materiaalit sekä menetelmät, tulokset esimerkki- havaintoineen ja tiivistetysti johtopäätökset liittyen maitotilayrittäjien tekemään ennakointityöhön osana yrityksensä strategista päätöksentekoa.

\section{Materiaalit ja menetelmät}

Kirjallisuuskatsauksen materiaalina ovat pääosin sähköisessä muodossa olevat artikkelit. Artikkelitietokannoista on tehty hakuja käyttäen hakusanoja sekä hakusanayhdistelmiä (Taulukko 1.). Kirjallisuuskatsaus on läpileikkaus tutkimusaihetta käsittelevään kirjallisuuteen ja tieteellisiin artikkeleihin. Kirjallisuuskatsaus alkaa tutkimusteemaan liittyvien avainsanojen määrittämisellä ja näiden avulla tehdyillä aineistohauilla. Kirjallisuuskatsauksen laatimista auttaa tutkimukselle hyödylliseksi tunnistetun kirjallisuuden koostaminen kartaksi. Tämä edesauttaa hahmottamaan tutkimusaiheeseen liittyviä tehtyjä tutkimuksia, tutkimuksellisia koulukuntia, tutkimussuuntia sekä tutkimusmenetelmiä. Nämä edistävät omaa tutkimusta ja tutkimusta tukevan kirjallisuuden jäsentelyä. Tämän myötä on myös helpompi tutkimuksen tulosten käsittelyn yhteydessä sitoa omaa tutkimusta aiempiin tutkimuksiin, kun ne ovat selkeästi tutkijalla esillä (Creswell 2009).

Kirjallisuuskatsauksen laatimiseksi käytettiin avainsanoja ja sanayhdistelmiä, jotka ovat esitetty taulukossa 1. englanninkielisinä kuten hakuja tehdessä käytettiin. Hakuja tehtiin tietokannoista ja artikkelihakemistoista, erityisesti tarkastelussa olivat Elsevier, Emerald ja Springer sekä niiden tuottamat artikkelihakutulokset. Aikajänne hakujen tekemiseen oli kesäkuu-joulukuu 2017.

Ennakointiin liittyvää materiaalia haettiin myös kansainvälisten organisaatioiden kuten Euroopan unionin ja Yhdistyneiden kansakuntien alaisten organisaatioiden julkaisutietokannoista samoilla hakusanoilla kuin käytettiin artikkelitietokantahauissa.

Taulukko 1. Hakusanoja kirjallisuuskatsauksen laatimiseksi

\begin{tabular}{|c|c|c|c|}
\hline \multicolumn{4}{|c|}{ Keywords and keyword combinations used in the literature search } \\
\hline foresight & $\begin{array}{l}\text { foresight AND } \\
\text { agriculture }\end{array}$ & $\begin{array}{l}\text { foresight AND dairy } \\
\text { farming }\end{array}$ & $\begin{array}{l}\text { strategic foresight } \\
\text { AND agriculture }\end{array}$ \\
\hline $\begin{array}{l}\text { strategic foresight } \\
\text { AND dairy } \\
\text { management }\end{array}$ & $\begin{array}{l}\text { foresight agriculture } \\
\text { AND management }\end{array}$ & foresight methods & $\begin{array}{l}\text { foresight methods } \\
\text { AND agriculture }\end{array}$ \\
\hline $\begin{array}{l}\text { foresight methods } \\
\text { AND SME }\end{array}$ & $\begin{array}{l}\text { driving forces AND } \\
\text { strategic management }\end{array}$ & $\begin{array}{l}\text { agriculture AND } \\
\text { driving forces }\end{array}$ & $\begin{array}{l}\text { dairy farm } \\
\text { management }\end{array}$ \\
\hline $\begin{array}{l}\text { strategic management } \\
\text { AND dairy farming }\end{array}$ & $\begin{array}{l}\text { business foresight } \\
\text { AND agriculture }\end{array}$ & $\begin{array}{l}\text { business foresight } \\
\text { AND SME }\end{array}$ & \\
\hline
\end{tabular}




\section{Tulokset}

Aineistohakujen tuloksena on tunnistettu artikkeleita, joissa tutkimusaihetta sivutaan tai käsitellään jossain muodossa. Artikkelihaku tuotti runsaan määrän tuloksia, jotka on läpikäyty tarkastellen avainsanojen osuvuutta, kunkin artikkelin kohdeaineiston ominaisuuksia, artikkelin hyödyllisyyttä keskittyen yrittäjien käyttämien ennakointikanavien ja -metodien selventämiseen. Hakuja tehtiin aikavälillä kesäkuu-joulukuu 2017 noin 15 kertaa ja käyttäen eri hakusanayhdistelmiä (Taulukko 1.). Kultakin kerralta valikoitui 5-10 artikkelia tarkempaan tarkasteluun ja nämä luokiteltiin eri teemoittain. Kaikki hakusanat eivät kuitenkaan tuottaneet relevantteja hakutuloksia, tällainen oli esimerkiksi yhdistelmä business foresight AND agriculture. Tämän haun kautta löytyi lähinnä laajempaan maatalouden kontekstiin ja globaaleihin kehityssuuntiin liittyviä artikkeleita, ei niinkään yritystason ennakointiin maataloudessa liittyviä tuloksia. Hakujen tuloksia on tiivistetty Kuvaan 2., jossa on luokiteltu artikkelihaun tuloksia avainsanojen alle sekä muodostettu kirjallisuuskartan runko hahmottamaan ja jäsentelemään aineistoa.

Yleisempi ennakointiin keskittyvä tutkimus on laajasti julkaisuissa käsiteltyä ja useasta eri näkökulmasta. Näihin aiheisiin liittyviä artikkeleita löytyy hyvin ja ennakointia eri tavoin kuvaten. Julkaisuiden avulla voi halutessaan rakentaa laajemman näkemyksen ennakoinnin kehittymisestä, erityisesti mikäli tarkastelukohteena ovat isot yritykset. Pk-yritysten ja omistajayrittäjien tekemästä ennakoinnista on myös löydettävissä julkaisuja, joskaan ei yhtä laajasti kuin suuryrityksiä koskien. Luonnollinen selitys tähän löytyy resursseista, jotka yrityksillä on käytettävissään.

Ennakointia itseään sekä ennakointiin liittyviä metodeja ja malleja ovat käsitelleet mm. Piirainen ja Gonzalez (2015) sekä Saritas ja Smith (2011). Jälkimmäiset ovat kuvanneet toimintaympäristön muutosten tarkasteluun liittyviä vaikuttajia, kuten heikkoja signaaleja, villejä kortteja sekä trendejä ja megatrendejä, osana tutkimusraporttiaan. Tilley ja Fuller (2000) ovat artikkelissaan keskittyneet kuvaamaan pk-yritysten suhdetta kestävään kehitykseen ja niitä ennakointimenetelmiä, joita pkyrityksissä käytetään toimintaympäristön tarkastelussa. He myös toteavat ennakointimenetelmien poikkeavan toisistaan koulukunnasta riippuen ja painottavat ennakointimenetelmien valinnassa eri vaihtoehtojen syvällistä pohdintaa, jotta vältetään riskit esimerkiksi tietyn skenaarion valinnassa (Tilley ja Fuller 2000).

Vecchiato (2015) keskittyy kuvaamaan artikkelissaan kahden suuryrityksen harjoittamaa ennakointia ja niiden lähtökohtien eroja. Molemmissa yrityksissä on määrätietoisesti tehty ennakointityötä, joka on ohjannut yritysten valintoja painopisteissä mm. tuotekehityksen osalta. Tässä artikkelissa todetaan (Vecchiato 2015) ennakoinnin olevan keino varautua ja löytää työkaluja mahdollisien kehityskulkujen toteutuessa, ei niinkään toimia ennusteena tulevasta. Fidlerin (2011) näkökulma yhdistää ennakoinnin ja strategisen johtamisen. Hän kiinnittää erityisesti huomiota strategisen johtamisen ja ennakoinnin vähäiseen linkittymiseen organisaatioiden tasolla. Ennakoinnin Fidler (2011) määrittää olevan toimiville organisaatioille välttämätöntä määrätietoista tiedonhankintaa ja analysointia päätöksenteon tueksi.

Hollantilaisten maidontuottajien suhtautumista toimintaympäristön muutoksiin ja niiden vaikutusta yrittäjien päätöksentekoon ovat tutkineet Ondersteijn ja kumppanit (2006). He havaitsivat vähemmän koulutettujen yrittäjien olevan varovaisempia toimintaympäristöstään tekemien tulkintojen osalta ja valitsevan hajauttamisen strategian tai tiukan tuotannonohjauksen strategian yritystoiminnan suuntaa ohjaamaan. Tämän oletettiin johtuvan vähemmän koulutettujen yrittäjien kyvystä tulkita toimintaympäristön muutoksia ja niiden vaikutuksia yritystoimintaan. 


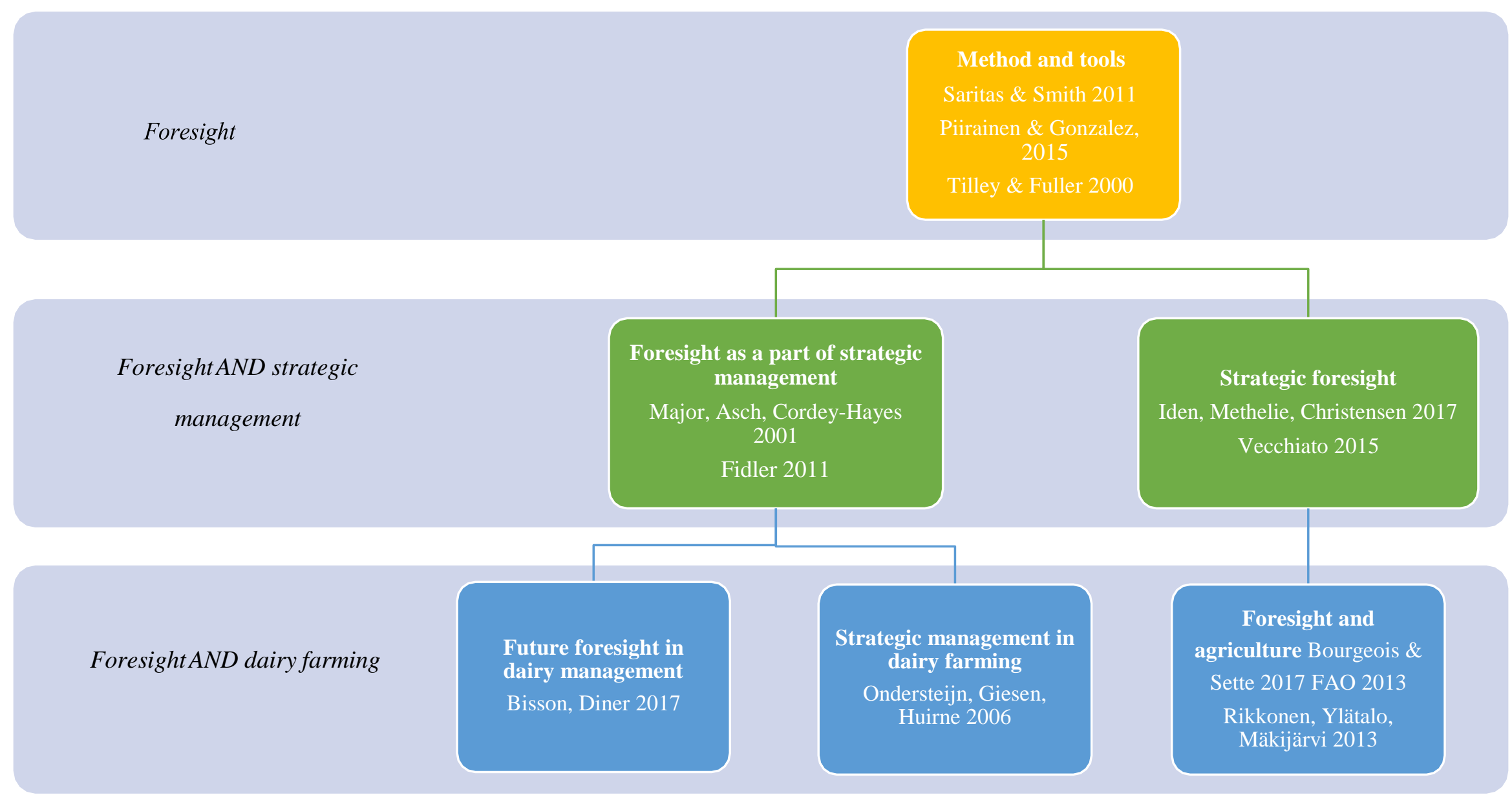

Kuva 2. Kirjallisuuskartta jäsentämään artikkelihakutuloksia, painopisteenä maidontuotantoon ja/tai maatalouteen liittyvät vertaisarvioidut artikkelit ja kansainvälisten organisaatioiden julkaisut 


\section{Johtopäätökset}

Kirjallisuuskatsauksen pohjalta ovat tarkentuneet ne aihealueet, joita on syytä tarkemmin empiirisesti tutkia ja joihin perehtymällä on saatavissa uutta tietoa mm. maatalousalan koulutuksen tueksi. Tutkimus ei ole jättänyt huomioimatta SWOT-analyysistä tuttujen elementtien analysointia ja pohdintaa osana maidontuotantoyrityksen strategista suunnittelua vaan ne ovat vahvasti läsnä yleisesti maatalousyrityksen johtamiseen liittyvissä artikkeleissa. Sen sijaan artikkelihakujen myötä vahvistui ennakkokäsitys pk-yritysten ja maatalousyritysten osalta melko pienestä ennakointitutkimuksesta, jossa asiaa tutkitaan yrittäjiltä itseltään kysyen. Jonkin verran suomalaisessa maataloustutkimuksessa on asiaa sivuttu, mutta erityisen laajaa tutkimustyö tältä osin ei ole vertaisarvioiduista artikkeleista etsittynä ja kansainvälisesti tarkasteltuna. Syynä tässä voi olla tulevaisuudentutkimus kehittyvänä tieteenalana ja aiempi maatalouden rakenne, joka ei ole pakottanut yrittäjiä nykyisen kaltaisesti vastaamaan nopeasti liikkuviin markkinatilanteen muutoksiin sekä varautumaan epävarmuuteen.

\section{Kirjallisuus}

Bisson, C. \& Diner, Ö.Y. 2017. Strategic early warning system for the French milk market: a graph theoretical approach to foresee volatility. Futures 87:10-23.

Bourgeois, R. \& Sette, C. 2017. The state of foresight in food and agriculture: challenges for impact and participation. Futures 93: 115-131.

Creswell, J.W. 2009. Research design. Qualitative, quantitative and mixed methods approach. $3^{\text {rd }}$ edition. SAGE Publications. $260 \mathrm{~s}$.

Fidler, D. 2011. Foresight defined as a component of strategic management. Futures 43: 540-544.

Food and Agriculture Organization of the United Nations (FAO) 2013. Horizon scanning and foresight. An overview of approaches and possible applications in food safety. Background paper 2. FAO early warning/rapid alert and horizon scanning. Food Safety Technical Workshop, in October in Rome, Italy. http://www.fao.org/3/a-i4061e.pdf

Iden, J., Methelie, L.B. \& Christensen G.E. 2017. The nature of strategic foresight research: a systematic literature review. Technological Forecasting \& Social Change 116: 87-97.

Marjo, E., Asch, D. \& Cordey-Hayes, M. 2001. Foresight as a core competence. Futures 33: 91-107.

Niemi, J. \& Väre, M. 2016/2017. Suomen maa- ja elintarviketalous. Luonnonvarakeskus, Helsinki. 88 s. https://jukuri.luke.fi/bitstream/handle/10024/538932/luke- luobio_17_2017.pdf?sequence=5\&isAllowed=y

Olson, K. 2004. Farm Management: principles and Strategies. Iowa State Press. 429 s.

Ondersteijn, C.J.M., Giese,n G.W.J. \& Huirne, R.B.M. 2006. Perceived environmental uncertainty in Dutch dairy farming: the effect of external farm context on strategic choice. Agricultural Systems 88: 205-226.

Piirainen, K.A. \& Gonzalez, R.A. 2015. Theory of and within foresight - "What does theory of foresight even mean?” Technological Forecasting and Social Change 96: 191-201.

Rikkonen, P., Ylätalo, M. \& Mäkijärvi E. 2013. Defining foresight activities and future strategies in farm management: empirical results from Finnish FADN farms. International Journal of Agricultural Management 3: 3-11.

Sarita,S.O. \& Smith, J.E. 2011. The Big Picture - trends, drivers, wild cards, discontinuities and weak signals. Futures 43: 202-212.

Suomen Itsenäisyyden Juhlarahasto SITRA 2017. Megatrendit 2017.

https://www.sitra.fi/aiheet/megatrendit/\#megatrendit-2017

Suomen virallinen tilasto (SVT) 2017. Lypsykarjatilojen määrä karjakokoluokittain. Helsinki:

Luonnonvarakeskus, http://stat.luke.fi/metsanhoito-ja-metsanparannustyot

Tilley, F. \& Fuller, T. 2000. Foresight methods and their role in researching small firms and sustainability.

Futures 32: 149-161.

Valtioneuvoston kanslia 2017. Suomalaisen elintarvikeketjun menestyksen avaintekijät.

http://vnk.fi/documents/10616/3866814/7_2017_Suomalaisen+elintavikeketjun+menestyksen

+avaintekij\%C3\%A4t/9e7169af-31b9-4458-a341-7ac2bdca1c4e?version=1.0

Vecchiato, R. 2015. Strategic planning and organizational flexibility in turbulent environments. Foresight 17: 257-273. 